Open Access

\title{
Toward an improved understanding of immigrant adaptation and transnational engagement: the case of Cuban Émigrés in the United States
}

Zoua M Vang ${ }^{1 *}$ and Susan E Eckstein ${ }^{2}$

* Correspondence: zoua.vang@mcgill.ca

'Department of Sociology, Centre on Population Dynamics, McGill University, 713 Leacock Building, 855 Sherbrooke Street, Montreal, QC H3A 2T7, Canada

Full list of author information is available at the end of the article

\begin{abstract}
The article compares the explanatory power of assimilationist and transnational frameworks with a historically informed generation (historical cohort) thesis that addresses the long-term cross-border impact of premigration experiences on immigrant new country adaptation. It tests the utility of the thesis with respect to immigrant remittance-sending among different waves of Cuban émigrés to the United States, who had different homeland experiences before uprooting. Regression analysis is used to assess the relative import of premigration experiences and factors immigration studies have found to be associated with assimilation and transnationalism. The article concludes with a discussion of the applicability of the historical cohort thesis for improved understanding of other immigrant group adaptation and homeland engagement.
\end{abstract}

Keywords: Transnationalism; Cuban immigrants; Remittances; Assimilation; Cohort analysis

\section{Introduction}

Since the late 1900s many developing countries have received record levels of remittances, transnational people-to-people income transfers, from their diasporas. In 2012, remittances to Latin America alone totaled \$61 billion (Maldonado and Hayem, 2014). Many Latin American countries received more hard currency from remittances their emigrants sent friends and family who had not uprooted than from bilateral and multilateral foreign aid. Mounting poverty and limited economic opportunities in the developing world spearheaded a surge in immigration, on which the growth in remittances rests.

Remittances are a manifestation of immigrant homeland engagement. Yet, immigrants differ in their cross-border involvement in ways that existing transnational, much less assimilation, theories inadequately account for. A historically grounded framework that takes premigration experiences into account (hereafter referred to as the historical cohort thesis) will be shown, below, to deepen the understanding of variability in patterns of remittance-sending, and hence transnational engagement, among first generation immigrants. According to the thesis, experiences shared in late adolescence and early adulthood, and later-in-life traumatic events, such as economic crises 
and major political upheavals, have enduring effects on people's worldviews and behavior, including if they relocate in another country.

In this article we elaborate and test the explanatory power of the historical cohort thesis to account for differences in remittances sent by Cuban immigrants who uprooted at different times with different lived experiences. We do so by drawing on a double birth and migration cohort model that enables us to operationalize premigration experiences while controlling for potentially confounding duration and period effects. In the conclusion we discuss the applicability of the historical cohort thesis for improving the understanding of transnational engagement among other immigrant groups.

\section{Overview of Cuban Émigré Remittance-sending}

The Cuban American experience demonstrates that immigrants do not necessarily share new country earnings with family members in their homeland, even when they adapt well economically in their new land. Cuban immigrants remit far less than most Latin American immigrants in the US, despite earning more (Orozco, 2005). In 1990 Cuban Americans remitted a mere $\$ 50$ million (Orozco, 2005). In contrast, money remitted in the same year to El Salvador - a country whose diaspora in the US is similar in size to Cuba's (Motel and Patten, 2012)—totaled \$366 million (World Bank, 2015). By 2012, remittances to both countries increased. Although those sent to El Salvador remained greater, the differential diminished: $\$ 2.6$ billion to Cuba (Morales, 2013), \$3.6 billion to El Salvador (World Bank, 2015). ${ }^{1}$ As of the first decade of this century more than half of all Cuban Americans in Miami, and $41 \%$ nationwide, sent remittances. They often shared earnings with two or more people in Cuba. Eighty-six per cent of them sent money at least twice yearly (Bendixen and Associates, 2005: 11-12).

The increase in Cuban American remittances has partly rested on the development of an institutional milieu in Cuba conducive to immigrant income-sharing (See Duany 2011 for discussion on institutional factors influencing ties between the Spanish Caribbean, including Cuba, and the US). In 1993 the Cuban government legalized use of the dollar and expanded opportunities to spend dollars. It also removed barriers to diaspora visits, which deepened transnational bonding and income-sharing (Eckstein, 2009). ${ }^{2}$ Meanwhile, Cubans came to covet dollars more as the value of their peso earnings plunged with the economic crisis that ensued when the Soviet Union fell apart and Soviet aid and trade ground to a precipitous halt, and as the range of goods purchasable only in hard currency expanded.

Against this backdrop, US Cuban travel and remittance policy vacillated. In the postCold War it was most restrictive in election years when incumbent presidents running for reelection appealed to the Cuban American electorate in Florida, the largest "swing" state (Eckstein, 2009: Chapter Three). Most Cuban American voters emigrated in the first two decades of Castro's rule, and most of them favored an embargo of Cuba, including at the people-to-people level. Only under President Barak Obama were most restrictions on Cuban American rights to visit and send remittances to Cuba lifted; as post-Soviet era émigrés came to account for an ever growing proportion of the Florida Cuban American community, more were predisposed to homeland engagement.

Fluctuations in US policy notwithstanding, Cuban American remittance-sending increased after 1990. It increased primarily among post-Soviet era émigrés. For example, in Miami in 2003 the more recent arrivals were nearly four times as likely 
as Cubans who emigrated immediately after the 1959 revolution to send $\$ 1,000$ or more (Institute for Public Opinion Research/Florida International University, 2004). Nationwide as well, recent émigrés have been found to be the most likely to send remittances (Bendixen and Associates, 2005; Bendixen, 2009).

What accounts for the different remittance-sending behavior of first generation Cuban immigrants who uprooted in different years? In the next section we briefly summarize three theoretical frameworks relevant for understanding variation in crossborder economic ties.

\section{Theoretical frameworks}

\section{Assimilation}

For most of the twentieth century both conventional wisdom and sociological theory focused on immigrant assimilation. Assimilation analyses typically highlighted how the longer immigrants lived in a new country, the greater their acculturation and overall integration, owing to their exposure to the ways of their new land (see Alba and Nee 2003 for a review of this perspective). Some scholars refer to this post-migration dynamic as the duration effect (Chiswick, 1978; Myers and Lee, 1996). ${ }^{3}$ Building on the assimilation paradigm, host country adaptation has also been shown to vary with age at time of migration: the younger the age, the greater the assimilation and acculturation (Rumbaut, 2004). Younger immigrants are better able to learn the language of their adopted country and take advantage of labor market opportunities.

Assimilation focused studies tend to neglect, analytically and empirically, immigrant homeland engagement and how it may impact on new country assimilation. Implicitly, if not explicitly, their paradigmatic perspective suggests that homeland ties diminish the longer immigrants live in their adopted country. Differences in remittance-sending would, accordingly, be expected to vary inversely with length of new country residence and associated exposure to assimilation forces, as well as with age at migration. Younger immigrants would be assumed both to uproot with weaker homeland ties and to integrate more readily into their new land.

\section{Transnationalism}

Since the 1990s a new frame of analysis has focused on immigrant transnational engagement. This conceptual frame highlights how immigrant lives may become embedded across borders (Glick-Schiller, Basch and Blanc-Szanton, 1992; Massey, Goldring and Durand, 1994; Portes, Guarnizo and Landolt, 1999). Contemporary conditions, such as technological advancements facilitating cross-border travel, communication, and remittance-sending, and new government interest in and facilitation of diaspora homeland involvement, provide bedrock for the build-up and maintenance of transnational ties (Kivisto, 2001). While transnational analyses have tended to downplay assimilation forces, Levitt and Glick-Schiller (2004) have highlighted the potential simultaneity of assimilation and transnational involvement.

From the vantage point of a transnational perspective, there is no a priori reason to expect immigrants' cross-border ties to diminish with the passage of years in their new country or with acculturation. Rather, transnational ties depend on such factors as immigrant earnings, experiences of discrimination in the receiving country, presence of 
family in the homeland, and government tolerance and encouragement of hometown associations and other formal as well as informal homeland ties (Levitt, 2001). Indeed, empirical studies suggest that homeland engagement does not necessarily weaken with length of new country residence. For example, Itzigsohn and Saucedo (2002) found age at migration (whether older or younger than 12 years of age), but not years since emigration, to be associated with cross-border sociocultural engagement and remittancesending among Columbian, Salvadoran, and Dominican immigrants they studied. In a similar vein, Waldinger (2008) and Schans (2010) found that length of residence in a new country was not a statistically significant predictor of remittance-sending among, respectively, Hispanics in the US and Turkish, Moroccan, Surinamese and Antillean origin immigrants in the Netherlands.

Yet, neither the transnational nor the assimilation frame of analysis address, analytically or empirically, how premigration experiences impact on immigrant adaptation and transnational engagement. In contrast, the historical cohort thesis does.

\section{Premigration historical cohort thesis}

Karl Mannheim's (1952) seminal work on historical generations and Norman Ryder's (1965) on cohorts serve as foundation for the historical cohort thesis. ${ }^{4}$ Mannheim's concept of socially constructed generations formed during late adolescence and early adulthood is pivotal for understanding how premigration experiences shape longlasting views on life. During these years individuals are old enough to reflect on their past and consider alternatives, and, as a result, develop their own distinctive sociopolitical consciousness through which they interpret later-in-life experiences. Accordingly, people who grow up in the same place but at different times or at the same time but in different places with different lived experiences, would be expected to differ in their perspectives on life.

As enduring as early-in-life experiences are, Ryder argued that traumatic later-in-life experiences, such as revolutions and economic crises, may lead adults to rethink their past and modify their outlook on life. His thesis suggests that different birth cohorts can share similar worldviews if they together experience the same traumatic historical events. While neither Mannheim nor Ryder focused on immigrants, if early-in-life and traumatic later-in-life experiences are enduring in their effect, immigrants' pasts might continue to influence their behavior after resettling in another country.

Some studies have noted enduring effects of premigration experiences on immigrant adaptation. Studies of political incorporation, for example, have shown immigrants' civic attitudes and engagement to be influenced by political conditions in their homeland, particularly by how repressive homeland regimes were (Bloemraad, 2006; Bilodeau, 2008). Yet, these studies provide no analytic framework for understanding how and why premigration experiences shape life after people move to a new country.

The historical cohort thesis, in contrast, anticipates that coming-of-age and traumatic later-in-life premigration experiences shape new country adaptation, especially when immigrants uproot old enough to have well-formed life perspectives of their own. Premigration experiences would be expected to remain especially consequential when immigrants with shared experiences resettle in close proximity to, and socialize with, one another. 
Eckstein and Barberia (2002) and Eckstein (2009), have demonstrated the utility of the historical cohort thesis in their qualitative analyses, which showed how Cuban immigrants with different premigration experiences adapt differently economically, socially, and politically in the US and relate differently to their homeland. However, to date the thesis has not been systematically assessed with quantitative data, and in relation to assimilation and transnational theses that focus on post-migration life.

\section{Premigration experiences of different waves of Cuban immigrants}

Cuban immigrants experienced 'different Cubas' depending on when they were born and when they emigrated. This was especially true of Cubans who came of age before the revolution, during Cuba's radical revolutionary makeover, and amidst the economic crisis that ensued when Soviet aid and trade ended after the dissolution of the Soviet Union. Mannheim's and Ryder's frameworks, combined, give reason to anticipate Cubans with different premigration experiences to take on distinctive views on life.

\section{The Pre-revolution formed generation: self-defined exiles}

Many Cubans became deeply committed to the revolutionary transformation that Fidel Castro inspired and oversaw after assuming power in 1959. They accordingly took on values of the new society for themselves (Eckstein and Krull, 2009). This was particularly true of adolescents and young adults at the time, who were captivated by the new government's initial utopian mission to create a more egalitarian and non-materialistic society. It was true also of many of the previously underprivileged, who perceived themselves as beneficiaries of the revolution.

Not all Cubans responded positively, however, to the country's radical makeover. Wealthy conservative Cubans who came of age before the revolution reacted hostilely to the socio-political transformation as they lost both their source of livelihood with expropriation of businesses and property and their lifestyle when the government shuttered private clubs and private schools (del Toro, 2003). Perceived through prerevolution formed lenses, the revolution represented a rejection of all for which they stood. On the losing side of history, many of them fled the country and settled in the US, especially in Greater Miami. They soon were joined by medium and small business owners as their properties, in turn, were nationalized, and by some workers and political activists who, though anti-Batista, became disillusioned with Castro's embracement of socialism and Marxism-Leninism (Eckstein, 2009: Table 1.1). Despite certain class and other differences among them, the approximately 600,000 Cubans who moved to the US between 1959 and 1979 together interpreted their exodus politically. They referred to themselves as 'exiles', and wanted nothing to do with 'Castro's Cuba' (Eckstein, 2009: 11).

While we are primarily concerned with comparing the entire self-defined exile cohort with post-Soviet era arrivals, we differentiate between what we call Early and Late Exiles. Early Exiles are those who emigrated between 1959 and 1965. Building on their premigration-formed social networks, which they reestablished in Miami, and on premigration attained skills and other assets, they adapted well economically (Portes and Stepick, 1993). They also successfully developed political capital which they used to convince US policymakers to maintain an embargo of their homeland at both the 
macro and people-to-people levels. Late Exiles emigrated between 1965 and 1979 (but mainly between 1965 and 1973, years during which the US and Cuban governments allowed substantial immigration, in what Washington dubbed Freedom Flights). Like Early Exiles, they tended to have come of age before the revolution and to have prerevolution formed views on life. They accordingly tended to adopt Early Exile's mentality for themselves. Many of them would have left earlier had they been able to do so.

The 1980s Mariel generation: émigrés with diverse mixes of Pre-revolution and revolution experiences

In 1980 some 125,000 additional Cubans emigrated from the port of Mariel (after which few Cubans emigrated for the remainder of the decade) (Masud-Piloto, 1995). These Cubans experienced the country's radical makeover, which included a massive expansion of schooling and healthcare and a dramatic reduction in income inequality, but also nationalization of most of the economy, forced participation in state linked workplace and neighborhood associations and in the military, as well as austerity. Compared with Exiles, Mariels were far more working class, darker skinned, and diverse in age (Eckstein, 2009). Age diversity reflected variation in premigration experiences. Like Exiles, the oldest Mariels viewed the revolution negatively through pre-revolution formed lenses. The youngest Mariels, in contrast, only knew firsthand Cuba transformed by revolution. For this reason, Mariels do not represent a pure, ideal-typical historical cohort filtering Cuba through distinctive lenses of their own. Notwithstanding age related differences among them, as a group Mariels understood the complexities of the revolution better than Exiles, and, consequently, were more tolerant of ties with Cuba and Cubans.

\section{New Cubans: post-soviet Era arrivals}

The ending of Soviet aid and trade, with the dissolution of the Soviet Union, caused an economic crisis (Mesa-Lago, 2000). The government responded by declaring a Special Period, a euphemism and legitimation for unprecedented austerity. Food became scarce and subsistence no longer affordable on previously adequate state earnings.

The crisis left an indelible mark on Cubans' expectations, values, and social relations, and caused state influence over people's lives to diminish (Hernández, 2005). The trauma was so great that Cubans' life perspective changed. Although the crisis affected everyone, and led many of the older generation to abandon their earlier commitment to the revolution, it left its greatest mark on youth who came of age to interpret life for themselves in the context of the shattered revolutionary project (Domínguez, 2005: 164). The younger generation took on an outlook very different from their age counterparts at the time of the country's radical makeover. The new generation was more pragmatic, less politicized, and had more materialistic values. They therefore came to view the diaspora more favorably than had the 'children of the revolution' who, believing in the revolutionary project, had severed ties with their compatriots who fled the country's radical transformation (Eckstein and Krull, 2009). In the context of the crisis Cubans also came to view individual emigration as part of a family project. Those who left were expected to share some of their earnings with relatives who remained in Cuba. Young adults were assumed to be the most employable abroad. 
The post-Soviet era émigrés, who we refer to as the New Cubans, differ both from the Mariel and Exile cohorts in their views about emigration, their homeland, and cross-border ties. Traumatized by the 1990s economic crisis, they envisioned themselves uprooting (much like other Latin American immigrants at the time) mainly for economic, or political along with economic, reasons (Eckstein, 2009: Appendix). Even politically disaffected New Cubans tended not to identify with Exiles, who they found politically intolerant, insensitive to hardships suffered by Cubans who lived through the revolution, and still committed to how people thought in Cuba before the revolution (Symmes, 2008). And New Cubans, unlike Exiles, had no desire to sever ties with their family who remained in Cuba (Eckstein, 2009).

Accordingly, the different waves of Cuban immigrants had different lived experiences before uprooting that generated different views on life. The remainder of the article assesses how these distinctive premigration experiences impact on Cuban émigré decisions to share income with relatives in Cuba.

\section{Data and methods}

We draw on cohort analysis to operationalize and evaluate the relative import of premigration experiences. Previous scholars have used a cohort framework to analyze immigrant adaptation. For example, Borjas (1985) deployed a cohort approach to estimate the effects of immigrants' human capital on their earnings, and Myers and Lee (1996; 1998), and Myers and Cranford (1998), modeled the effects of aging and length of US residence on immigrant housing attainment and occupational mobility. However, heretofore no scholar has conceptualized different immigration cohorts to capture historically grounded premigration experiences and their possible long-term cross-border impact. ${ }^{5}$

\section{Analytical issues}

Two methodological issues arise when examining immigrant adaptation with a cohort approach. First is the issue of variable identification. Similar to the age-period-cohort identification problem (Hobcraft, Menken and Preston, 1982), analysis of different immigration cohorts raises what is known as a duration-period-cohort identification dilemma (Myers and Lee 1996: 54). Since duration (years spent in the host country), period (year of data observation) and cohort (year of immigration) are linear functions of one another, including all three variables in a regression model would lead to perfect collinearity. Yet, it may be theoretically desirable to differentiate and include all three variables as predictors in a model. The second issue is the confounding of duration and immigration cohort (Myers and Lee, 1996). Researchers have typically used immigration cohort to represent effects owing to varying lengths of residence in the host country (Chiswick, 1978). This is problematic, however, since variation in a response variable for immigrants arriving in different years can be due to differences in length of residence, differences in observed and unobserved characteristics between cohorts, or both. This issue affects our analysis since historical cohorts are defined by year of immigration.

To address these problems, Myers and Lee (1996) proposed a double cohort method wherein observations from cross-sectional surveys at two time points are linked through dual birth and immigration year memberships to create synthetic cohorts that 
can be followed over time. We adopt their method, and in preliminary analysis not shown here (results available upon request), used a hierarchical backward model selection strategy to obtain the following reduced-form double cohort model:

$$
z=M+\kappa+\eta+\pi+(\kappa \cdot \pi)+(\eta \cdot \pi)
$$

where $M=$ a vector of control variables; $\mathrm{\kappa}=$ survey year; $\eta=$ birth cohort; $\pi=$ historical cohort; $(\kappa \cdot \pi)=$ temporal duration; and $(\eta \cdot \pi)=$ age at migration. The model resolves the identification problem because any period effects that may arise between the different years of observation are controlled for in the model by $\kappa$. Furthermore, we can directly model the effects of exposure to assimilation forces during the observation period with $(\kappa \cdot \pi)$. If time spent in the US decreases immigrants' propensity to send remittances, we should observe a negative coefficient on the interaction term. Note, however, that inclusion of (к. $\pi$ ) achieves partial disentanglement of duration and historical cohort effects because only temporal duration is directly measured; that is, the impact of having lived $n$ additional years in the US on top of however many years an immigrant already spent in the country at the time of first observation.

Since historical cohorts are defined by immigration year, it will not be possible to statistically isolate and assess the separate contributions of historical cohort and net duration (total time spent in the US) on remittance-sending (i.e., the two are still confounded within $\pi$ ). Theory, here, can aid in interpreting whether $\pi$ represents net duration effects, historical cohort effects, or both. According to assimilation theory, time spent in the host country should reduce remittance-sending. If $\pi$ is merely capturing net duration effects then we would expect to find a stepwise remittance gradient, with Early Exiles remitting the least because they have been in the US the longest, and New Cubans remitting the most because they are the most recent arrivals. Late Exiles and Mariels should be the second and third highest remitting groups, respectively, given their intermediate arrival years.

\section{Data and conceptualization of variables}

Our analysis draws on polls of Cuban Americans 18 years and older conducted in 2000 and 2007 by the Institute for Public Opinion Research and the Cuban Research Institute of Florida International University (FIU) (Cuban Research Institute, 2015). The Institute for Public Opinion Research and the Cuban Research Institute has conducted the only large-scale systematic survey of Cuban Amerians in multiple years. The institutes interviewed 1,709 Cuban Americans in Miami-Dade County in 2000, and 1,000 Cuban Americans seven years later. ${ }^{6}$ We restrict our analytical sample to 1,244 Cuba-born respondents who met our historical cohort and age selection criteria and had no missing information on our dependent and independent variables.

To construct our data, we first differentiated four historical cohorts based on reported immigration year in the 2000 poll: Early Exiles, 1959-64; Late Exiles, 1965-79; Mariels, 1980-89; and New Cubans, 1990-98. Next, the historical cohorts were assigned to five 10-year age groups based on reported age in 2000: 30-39, 40-49, 50-59, 60-69, and 70-79. In the 2007 poll we identified the same historical cohorts but assigned them to 10-year age groups who were seven years older: 37-46, 47-56, 57-66, 67-76, and 77-86. We then linked respondents across the two polls through their dual historical and birth cohort membership. The restricted age range facilitates comparisons 
across all historical cohorts. ${ }^{7}$ Taking 1998 as the end year of immigration, by the time of the first FIU poll all émigrés analyzed would have had at least two years in the US to secure work and attain earnings which they could remit to family of theirs still in Cuba.

\section{Dependent variable}

We assess remittance-sending based on the question, 'Do you or your relatives in Miami send money to relatives in Cuba?' The wording of this question raises some potential problems of variable misalignment. Misalignment is not an issue when there is a negative response (i.e., neither respondent nor relatives remit money). An affirmative response, however, means that either the respondent or relatives, or both, send money. Misalignment is not present when only the respondent remits or when both the respondent and relatives remit. Variable misalignment could, however, become an issue when the respondent answers 'yes', but only the relatives remit money. In such a situation, the predictors (which are based on respondent's characteristics) would not correspond with the outcome (which is based on the relatives' behavior). Noteworthy, though, family members often pool money to remit and consider remittances a family, not merely an individual, affair (Eckstein, 2009: Chapter Six). Consequently, we do not believe that variable misalignment poses a significant problem for our analysis. Moreover, we compared the proportion of remittance senders in the 2000 FIU poll with another survey, where Cuban respondents were asked specifically about their own remitting behavior, and found minimal differences. ${ }^{8}$

\section{Explanatory variables}

Our key explanatory variable of interest is historical cohort. Three assimilation variables are also tested in our analysis: temporal duration, age at migration, and acculturation. Temporal duration is measured with interaction terms between historical cohort and survey year $(\kappa \cdot \pi)$. Age at migration is measured with interaction terms between birth and historical cohorts $(\eta \cdot \pi)$. We also include an indicator of acculturation that has been analyzed in previous studies: language assimilation (Itzigsohn and Saucedo, 2002; Waldinger, 2008). ${ }^{9}$ Linguistic assimilation is measured with the question, 'Which language do you prefer to get your news in?' Although a direct question on English proficiency would have been preferred, news language preference is the only language related variable that is repeated in both surveys. Arguably, news language preference is related to language proficiency since some degree of comprehension is necessary to read or listen to news in a particular language. The variable is coded into three categories: Spanish-only (reference), English only, or Bilingual/Other. A preference for getting one's news in English (as opposed to Spanish or both English and Spanish) is a proxy for acculturation.

Some scholars have noted that immigrant earnings and the continuous presence of at least some close family members in the country of origin impact on cross-border ties, especially remittance-sending (Diaz-Briquets and Perez-Lopez 1997; Itzigsohn and Saucedo, 2002). ${ }^{10}$ We therefore include in our analysis immigrant household income and relatives in Cuba as possible predictors associated with the transnational framework. A dummy variable is used to capture the presence of close family in Cuba $(0=$ no, $1=$ yes). We construct household income as a four category variable: < \$20 K (reference), \$20-\$50 K, \$50 K+, and income missing.

Lastly, age (birth cohort) and period (survey year) are included as control variables. The reference categories for age group and period are 40-49 (47-56 in 2007) and 2000, 
respectively. Gender ( $1=$ male, $0=$ female $)$ and marital status $(0=$ married, $1=$ single, and $2=$ divorced/other ) are additional demographic controls that have been analyzed in previous studies of transnationalism and thus are included in our models (Schans, 2010; Waldinger, 2008; Itzigsohn and Saucedo, 2002). ${ }^{11}$

\section{Analytical strategy}

We fit five double cohort models to assess the explanatory power of the assimilation, transnationalism, and historical cohort frameworks. Model 1 establishes baseline differences in remittance-sending among the historical cohorts, net of period, age, marital status, and gender. Model 2 includes the transnationalism predictors. Models 3 through 5 tests assimilation predictors associated with acculturation, temporal duration, and age at migration, respectively.

\section{Results}

\section{Descriptive findings}

Means and standard deviations for the covariates by historical cohort are shown in Table 1. The historical cohorts differ from one another with respect to age, gender, news language preference, family-in-homeland, and household income. Early and Late Exiles are older on average than Mariels and New Cubans. Forty-nine and $52 \%$ of Early and Late Exiles, respectively, are age 60 or older, compared with $30 \%$ and $21 \%$ of Mariels and New Cubans. There are slightly more female respondents represented among Late Exiles, whereas gender is more balanced for the other cohorts. Early Exiles include more high-income earners (37 \% have annual household incomes of $\$ 50,000$ or more). In contrast, there were fewer proportions of Late Exiles, Mariels, and New Cubans, who had such high earnings (23, 19 and $13 \%$, respectively). All cohorts have significant family ties. Even Early and Late Exiles, who have been in the US for more than 30 years on average, claim to still have close family in Cuba (54 and $78 \%$, respectively).

Historical cohorts also exhibit different proclivities to send remittances. Long-term émigrés tend to remit less than more recent arrivals. At first glance, these unadjusted proportions suggest that duration may be the underlying cause of the cohort variation in remittance-sending-that is, the longer émigrés have been in the US, the weaker their economic ties. But, as demonstrated below, this is not the case. These descriptive statistics mask complex patterns of remittance-sending among the four historical cohorts that cannot be fully explained by assimilation forces alone.

\section{Multivariate regression findings}

Results from multivariate logistic regressions predicting remittance-sending are shown in Table 2. The coefficients are presented as odds ratios (ORs) for ease of interpretation. The ORs for the historical cohort dummy variables indicate the difference in remittance-sending for each historical cohort relative to Early Exiles. We are interested in the full set of historical cohort comparison; hence, the Wald statistic was used to test the coefficient for each historical cohort against the others in models with main effects (see Table 3).

Model 1 assesses baseline differences in the odds of remittance-sending for Late Exiles, Mariels, and New Cubans relative to Early Exiles, net of age, period, gender and 
Table 1 Descriptive Statistics for Dependent and Explanatory Variables by Historical Cohorts

\begin{tabular}{|c|c|c|c|c|c|}
\hline & Early & Late & Mariels & New & \\
\hline & Exiles & Exiles & & Cubans & $p$-value \\
\hline Sent remittances & 27.84 & 39.86 & 47.74 & 72.56 & 0.000 \\
\hline \multicolumn{6}{|l|}{ Birth Cohort: } \\
\hline 30-39 (37-46 in 2007) & 4.19 & 11.66 & 15.41 & 37.67 & \multirow[t]{5}{*}{0.000} \\
\hline $40-49$ (47-56 in 2007) & 16.77 & 18.18 & 21.05 & 22.79 & \\
\hline $50-59$ (57-66 in 2007) & 29.64 & 17.72 & 33.46 & 18.14 & \\
\hline 60-69 (67-76 in 2007) & 26.95 & 31.00 & 18.42 & 14.88 & \\
\hline 70-79 (77-86 in 2007) & 22.46 & 21.45 & 11.65 & 6.51 & \\
\hline Survey Year & 49.41 & 52.45 & 30.07 & 21.39 & \multirow[t]{3}{*}{0.016} \\
\hline 2000 & 48.80 & 51.28 & 46.24 & 38.14 & \\
\hline 2007 & 51.20 & 48.72 & 53.76 & 61.86 & \\
\hline \multicolumn{5}{|l|}{ Gender } & \multirow[t]{3}{*}{0.007} \\
\hline Male & 42.22 & 34.50 & 45.49 & 46.05 & \\
\hline Female & 57.78 & 65.50 & 54.51 & 53.95 & \\
\hline \multicolumn{5}{|l|}{ Marital status } & \multirow[t]{4}{*}{0.160} \\
\hline Married & 64.97 & 67.37 & 61.28 & 63.72 & \\
\hline Single & 11.98 & 10.49 & 16.92 & 16.74 & \\
\hline Divorced/Other & 23.05 & 22.14 & 21.80 & 19.53 & \\
\hline \multicolumn{6}{|c|}{ Language preference for news } \\
\hline Spanish only & 41.92 & 63.4 & 78.2 & 85.58 & \multirow[t]{3}{*}{0.000} \\
\hline English only & 22.75 & 13.52 & 4.14 & 2.79 & \\
\hline Bilingual/Other & 35.33 & 23.08 & 17.67 & 11.63 & \\
\hline Have relatives in Cuba & 53.29 & 78.55 & 81.58 & 93.02 & 0.000 \\
\hline \multicolumn{5}{|l|}{ Household income: } & \multirow[t]{6}{*}{0.000} \\
\hline$<\$ 20 \mathrm{~K}$ & 23.05 & 30.07 & 32.33 & 33.49 & \\
\hline$\$ 20 \mathrm{~K}-\$ 50 \mathrm{k}$ & 20.96 & 27.74 & 30.45 & 40.47 & \\
\hline$\$ 50 \mathrm{~K}+$ & 37.43 & 22.61 & 18.05 & 12.56 & \\
\hline Income missing & 18.56 & 19.58 & 19.17 & 13.49 & \\
\hline N & 334 & 429 & 266 & 215 & \\
\hline
\end{tabular}

marital status. Late Exiles, Mariels, and New Cubans all have higher odds of remittance-sending than Early Exiles (OR 1.7, 2.0, and 5.0, respectively; $\mathrm{p}<0.001$ for each cohort). This suggests a historical cohort-remittance gradient consistent with an assimilationist framework. Formal tests contrasting the coefficients for Late Exiles, Mariels, and New Cubans against one another (see Table 3) show, however, that each successive cohort does not necessarily remit more than its predecessor. The difference in the odds of remittance-sending between Late Exiles and Mariels is not statistically significant $\left(\chi^{2}=1.2 ; \mathrm{p}\right.$-value $\left.=2.7\right)$. If assimilation forces are consequential, as the assimilation thesis predicts, then Late Exiles should remit less than Mariels, given the former group's longer stay in the US. Yet the two cohorts have the same odds of remitting money to relatives. The comparison of remittance-sending for New Cubans versus Late Exiles $\left(X^{2}=31.9 ; \mathrm{p}<0.001\right)$ and Mariels $\left(\mathrm{X}^{2}=19.5 ; \mathrm{p}<0.001\right)$ indicates exceptionally high odds of income-sharing for the newest émigrés. Thus, far from a simple 
Table 2 Odds Ratios from Double Cohort Logistic Regressions Predicting Remittance-sending $(\mathrm{N}=1,244)$

\begin{tabular}{|c|c|c|c|c|c|}
\hline & M1 & M2 & M3 & M4 & M5 \\
\hline \multicolumn{6}{|l|}{ Historical Cohort: } \\
\hline Late Exiles & $1.70^{* * *}$ & 1.28 & 1.30 & 1.39 & $2.65^{*}$ \\
\hline Mariels & $2.04^{* * *}$ & $1.55^{*}$ & $1.60^{*}$ & $1.81^{*}$ & $2.83^{*}$ \\
\hline New Cubans & $5.01 * * *$ & $3.39^{* * *}$ & $3.53^{* * *}$ & $3.61^{* * *}$ & $13.86^{* * *}$ \\
\hline \multicolumn{6}{|l|}{ Transnationalism predictors: } \\
\hline Relatives in Cuba & & $4.44^{* * *}$ & $4.50^{* * *}$ & $4.55^{* * *}$ & $4.68^{* * *}$ \\
\hline \multicolumn{6}{|l|}{ Household income } \\
\hline $20 k-50 k$ & & 1.24 & 1.25 & 1.25 & 1.25 \\
\hline $50 \mathrm{k}+$ & & 1.28 & 1.26 & 1.25 & 1.36 \\
\hline Income missing & & 0.81 & 0.81 & 0.81 & 0.83 \\
\hline \multicolumn{6}{|l|}{ Assimilation Predictors: } \\
\hline \multicolumn{6}{|l|}{ News language preference } \\
\hline English & & & 1.28 & 1.28 & 1.50 \\
\hline Bilingual or Other & & & 0.95 & 0.95 & 0.99 \\
\hline \multicolumn{6}{|l|}{ Temporal Duration $(\kappa \cdot \pi)$ : } \\
\hline Late Exiles 7 years later & & & & 0.87 & 0.83 \\
\hline Mariels 7 years later & & & & 0.80 & 0.77 \\
\hline New Cubans 7 years later & & & & 0.95 & 0.93 \\
\hline \multicolumn{6}{|l|}{ Age-at-Migration $(\eta \cdot \pi)$ : } \\
\hline \multicolumn{6}{|l|}{ Late Exiles } \\
\hline 30-39 (37-36 in 2007) & & & & & $0.10^{* *}$ \\
\hline 50-59 (57-66 in 2007) & & & & & 0.63 \\
\hline 60-69 (67-76 in 2007) & & & & & 0.58 \\
\hline 70-79 (77-86 in 2007) & & & & & 0.42 \\
\hline \multicolumn{6}{|l|}{ Mariels } \\
\hline 30-39 (37-36 in 2007) & & & & & 0.22 \\
\hline 50-59 (57-66 in 2007) & & & & & 0.98 \\
\hline $60-69(67-76$ in 2007) & & & & & 0.38 \\
\hline 70-79 (77-86 in 2007) & & & & & 0.76 \\
\hline \multicolumn{6}{|l|}{ New Cubans } \\
\hline $30-39$ (37-36 in 2007) & & & & & $0.08^{* *}$ \\
\hline 50-59 (57-66 in 2007) & & & & & 0.43 \\
\hline 60-69 (67-76 in 2007) & & & & & $0.17^{*}$ \\
\hline 70-79 (77-86 in 2007) & & & & & $0.07^{* *}$ \\
\hline Constant & $0.49^{* * *}$ & $0.15^{* * *}$ & $0.14^{* * *}$ & $0.13^{* * *}$ & $0.07^{* *}$ \\
\hline Log likelihood & -768.50 & -723.58 & -722.75 & -722.55 & -710.55 \\
\hline Psuedo $R^{2}$ & 0.10 & 0.15 & 0.15 & 0.15 & 0.17 \\
\hline
\end{tabular}

FIU Cuba Poll, 2000 and 2007

All models control for survey year (period), birth cohort (age), marital status, and gender ${ }^{*} \mathrm{p}<.05 ;{ }^{* *} \mathrm{p}<.01 ;{ }^{* * *} \mathrm{p}<.001$

pattern of weakening economic ties to family in Cuba for earlier arrivals, the findings suggest that historical cohorts differ in their remitting behavior and in ways not consistent with assimilationist interpretations. 
Table 3 Wald Statistics Comparing Remittance-sending for Late Exiles, Mariels, and New Cubans, Main Effect Double Cohort Regression Models $(N=1,244)$

\begin{tabular}{|c|c|c|c|c|c|c|}
\hline \multirow[b]{2}{*}{ Comparison } & \multicolumn{2}{|l|}{$\underline{M 1}$} & \multicolumn{2}{|l|}{ M2 } & \multicolumn{2}{|l|}{ M3 } \\
\hline & $x^{2}$ & $p$-value & $\overline{x^{2}}$ & $p$-value & $\overline{x^{2}}$ & $p$-value \\
\hline Mariels vs. Late Exiles & 1.24 & 0.266 & 1.23 & 0.268 & 1.47 & 0.226 \\
\hline New Cubans vs. Late Exiles & 31.86 & 0.000 & 23.52 & 0.000 & 23.46 & 0.000 \\
\hline New Cubans vs. Mariels & 19.47 & 0.000 & 13.96 & 0.000 & 14.08 & 0.000 \\
\hline
\end{tabular}

FIU Cuba Poll, 2000 and 2007

Next, we examine the effects of having relatives in Cuba and of household income on remittances (Model 2) while adjusting for historical cohorts, age, period, gender, and marital status. Earlier cohorts may remit less than more recent arrivals because they may no longer have close family members in Cuba. Family-in-homeland is positively associated with remittance-sending, as scholars of transnationalism posit. Émigrés are four times more likely to send remittances if they have close family members in Cuba (OR 4.4; $\mathrm{p}<0.001$ ). However, income has no bearing on remittance-sending and, most notably, does not explain why Early Exiles, with the highest income, currently and in years past have remitted the least. These results are robust across all the models.

Differences in remittance-sending between Early and Late Exiles are no longer statistically significant once transnationalism variables are included in Model 2, suggesting that Late Exiles' greater family ties in Cuba may be the main reason why they remit far more than Early Exiles. The results indicate that both transnationalism factors and premigration experiences may influence the remitting behavior of Late Exiles. Controlling for household income and family-in-homeland reduced the odds ratios for remittancesending in Models 1 and 2 by $47 \%$ for Mariels and $40 \%$ for New Cubans. Importantly, however, Mariels and New Cubans continue to differ significantly from Early Exiles and from one another in their remitting behavior (while differences between Mariels and Late Exiles are trivial). The fact that Mariels and New Cubans continue to differ from Early Exiles and from one another in their remitting behavior suggests that there is something different about these two émigré cohorts that cannot be reduced to mere differences in sociodemographic composition or transnationalism factors. Whether or not the cohort differences in remittance-sending are the result of differential exposure to assimilation forces is explored in the remaining models.

Assimilation forces might weaken commitment to family who remain in immigrants' homeland. We test the effect of acculturation in Model 3. News language preference, indicative of acculturation, proves not to be a statistically significant predictor of remittance-sending. The null finding for acculturation may reflect the fact that Spanish language retention is very high among all émigré cohorts (Eckstein, 2009: 52). Earlier arrivals may have a preference for their news in English, but they have not lost command of their mother tongue and are comfortable with both languages.

In Model 4 we test the impact of temporal duration on income-sharing. An additional seven years of residence in the US did not reduce émigrés' odds of sending remittances. The null finding for the Exile cohorts may reflect a saturation effect of duration. In other words, these émigrés have been in the country for well over 30 years and therefore the influence of time spent in the US on remittance-sending may have already taken its toll such that an additional seven years would have little effect. However, even during their early years of US settlement, when transnational bonds 
might be expected to be strong, pre-1990 émigrés resisted cross-border economic ties. Remittances in 1990, at the eve of the arrival of New Cubans (and prior to the first FIU survey), were, as previously noted, a mere $\$ 50$ million.

Duration might be expected to exert its greatest influence on New Cubans, given their fewer years in the US at the time of the 2000 poll. Yet, our data analysis points to a non-significant temporal duration effect among them as well. While seven years may be too short a time interval for assimilation forces to impact their remittance-sending proclivity, New Cubans had been in the US at least nine years by the time of the 2007 poll. A nine year window ought to pick up duration effects, if consequential.

Age at migration effects are assessed in Model 5. The odds ratios for the historical cohorts no longer reflect "main effects." Rather, they are conditional on birth cohort and reflect inter-historical cohort differences in remittance-sending for 40-49 year olds (47-56 in 2007). Statistically significant age at migration effects are observed for some birth cohorts among Late Exiles and New Cubans but not for Mariels. Meanwhile, age at migration significantly influences the income-sharing behavior of all New Cubans, except among 50-59 year olds. Yet, the results for New Cubans do not allow us to draw any firm conclusions about the effects of assimilation since those who uprooted when younger (30-39 year olds) and also when older (60 years and older) both have lower odds of remittance-sending than 40-49 year olds. ${ }^{12}$ Since all New Cubans in our sample emigrated when 21 or older, it is not clear why 40-49 year olds (who uprooted between the ages of 30 and 47) have higher odds of remittance-sending than all other birth cohorts. The significant age at migration effect observed for 30-39 year old Late Exiles seems to be consistent with an assimilation interpretation since these émigrés uprooted when younger, on average, than 40-49 year old Late Exiles (30-39 year old Late Exiles migrated between $<1$ and 17 years of age whereas $40-49$ year old Late Exiles migrated between 6 to 27 years of age). Yet, because of the overlap in the ages at migration for these two Late Exile age groups, it is not possible to determine how consequential the age 12 cut-off point is for remittance-sending.

\section{Further tests of duration and age at migration}

Until this point we relied on the absence of a historical cohort-remittance gradient to argue that assimilation forces were not responsible for the differences in remittancesending observed among the four historical cohorts. Our logic is premised on a negative linear relationship between time spent in the US (duration) and remittance-sending. However, as discussed earlier, it is not possible to statistically disentangle net duration effects from historical cohort effects since both are defined by immigration year. Additionally, we cannot determine if age at migration influences remittance-sending in ways consistent with assimilationist predictions.

Thus, we proceed to estimate two supplemental regular (i.e., non-double cohort) regression models to test the effects of net duration (total time spent in the US) and age at migration on remittance-sending for each historical cohort separately. Net duration is defined as the difference between survey year and immigration year. The presence of a statistically significant negative coefficient on the net duration variable would indicate evidence of assimilation forces weakening cross-border economic ties. It would also mean that the historical cohort differences observed in the double cohort 
regression models are due in part to variation in time spent in the US and not strictly the result of premigration historically-formed experiences as we hypothesized. We model age at migration as both a continuous and dichotomous explanatory variable. The dichotomous variable tests the effect of migration when age 12 or older versus younger (omitted category) on remittance-sending. Since, in our sample, there are only a handful of Mariels who migrated when younger than 12, and all of the New Cubans emigrated at age 21 or older, models with the dichotomous age at migration variable are estimated for the two Exile cohorts only. Model S1 tests the effects of net duration and continuous age at migration. Model S2 tests the effects of net duration and dichotomous age at migration. Both models control for survey year, gender, marital status, news language preference, relatives in Cuba, and household income.

The results from this additional analysis are shown in Table 4 . We only show the odds ratios for the net duration and age at migration variables (the effects of the other covariates are similar to those reported in the double cohort regression models). Contrary to assimilationist predictions, net duration does not weaken émigrés' odds of remitting money to relatives. The null finding for net duration is consistent across all four historical cohorts. The results confirm that the historical cohort differences observed in the double cohort regression models do not stem merely from variation in the length of time spent in the US.

The results for the continuous age at migration variable (Model S1) show statistically significant effects for New Cubans only. However, the effect is contradictory to assimilationist predictions. It is true that émigrés who uprooted at older ages are less likely to send remittances than those who emigrated when younger. However, since all New Cubans in our sample emigrated as adults, their childhood and adolescence were spent in Cuba. As such, assimilation forces associated with age at migration, especially for children younger than 12 , are not relevant. Thus, it is likely that the finding for

Table 4 Estimated Effects (Odds Ratios) of Duration and Age-at-migration from Logistic Regression Models Predicting Remittance-sending for Each Historical Cohort Separately

\begin{tabular}{|c|c|c|c|c|c|c|}
\hline & \multicolumn{2}{|c|}{ Early Exiles ${ }^{1}$} & \multicolumn{2}{|c|}{ Late Exiles ${ }^{2}$} & \multirow{2}{*}{$\begin{array}{l}\text { Mariels }^{3} \\
\text { Model S1 }\end{array}$} & \multirow{2}{*}{$\begin{array}{l}\text { New Cubans } \\
\text { Model S1 }\end{array}$} \\
\hline & Model S1 & Model S2 & Model S1 & Model S2 & & \\
\hline Net Duration & 0.98 & 0.99 & 0.97 & 0.97 & 0.95 & 0.92 \\
\hline \multicolumn{7}{|c|}{ Age at migration } \\
\hline Continuous & 0.97 & & 0.98 & & 0.98 & $0.96^{*}$ \\
\hline Dichotomous $^{a}$ & & 0.62 & & 0.55 & & \\
\hline Constant & 0.62 & 0.32 & 1.61 & 1.08 & 1.87 & 1.57 \\
\hline Psuedo $R^{2}$ & 0.10 & 0.10 & 0.09 & 0.09 & 0.11 & 0.20 \\
\hline N & 334 & 334 & 429 & 429 & 266 & 215 \\
\hline
\end{tabular}

FIU Cuba Poll, 2000 and 2007

${ }^{*} \mathrm{p}<.05$ All models control for survey year (period), gender, marital status, news language preference, relatives in Cuba, and household income. Model S2, with dummy variable for migration at age 12 or older, was not estimated for Mariels and New Cubans because of too few and zero cases of émigrés who uprooted when younger than 12, respectively ${ }^{1}$ Early Exiles had been in the US on average for 42.4 years (SD: 3.7). The ages at migration ranged between less than 1 and 42 years with a mean migration age of 20.4 years (SD: 11.1)

${ }^{2}$ Late Exiles had been in the US on average for 33.5 years (SD: 5.1). The ages at migration ranged between less than 1 and 54 years with a mean migration age of 27.9 years (SD: 12.8)

${ }^{3}$ Mariels had been in the US on average for 21.6 years (SD: 4.6). The ages at migration ranged between 10 and 66 years with a mean migration age of 35.6 (SD: 12.33)

${ }^{4} \mathrm{New}$ Cubans had been in the US on average for 10 years (SD: 4.2). The ages at migration ranged between 21 and

74 years with a mean migration age of 41.6 (SD: 12.5)

${ }^{a}$ Age 12 and older versus younger than 12 (reference category) 
New Cubans may simply reflect age (as opposed to age at migration) effects. Results for Model S2 indicate that 12 is not an important age at migration cut-off point for Early and Late Exiles' cross-border economic ties. There are trivial differences in remittance-sending among Late and Early Exiles who migrated when younger and older than 12. These results provide further evidence that differences in exposure to assimilation forces are not at the root of the variation in Cuban émigrés remittancesending.

\section{Conclusions}

The article tested a premigration, historically-informed cohort thesis to deepen the understanding of immigrant adaptation. Although earlier work (Eckstein and Barberia, 2002) deployed a historical cohort framework to investigate Cuban American adaptation in the US, it did not systematically assess the competing and/or complementary effects of assimilation and transnationalism forces. We make an important contribution to the immigration literature by demonstrating how premigration experiences, embodied in historical cohorts, combine with new country settlement and transnational factors, to influence cross-border economic ties-and, by implication, possibly other aspects of transnational engagement.

Our analysis showed post-Soviet era émigrés to be the most transnationally engaged, and émigrés who fled the revolution soon after Castro assumed power in 1959 the least so. These émigré cohorts had very different lived experiences before uprooting, which shaped their life-perspectives and how they relate, as a result, to their homeland from their new land. The first émigré cohort came of age before the revolution, and viewed their country's radical makeover through pre- and politicized, anti-revolution lenses. Perceiving themselves as exiles, they support an embargo of Cuba, including at the people-to-people level. In contrast, the post-Soviet era cohort's views on life were shaped by the crisis that ensued when the Soviet Union broke apart and Soviet aid and trade abruptly ended-a crisis that shattered belief in the revolutionary project. Mainly envisioning themselves as economic immigrants, they wish to maintain ties with and help family they left behind.

We examined possible explanations of variability in immigrant adaptation, linked to the assimilation framework, namely, length of time in the US, age at migration, and acculturation, and found neither temporal nor net duration to have significant effects on the remitting behavior of Cuban émigrés. Age at migration was predictive of immigrants' propensity to remit, but only for some age-groups among Late Exiles and New Cubans. Furthermore, the presumed age- 12 threshold was not supported by the empirical analysis. Acculturation, as measured by news language preference, also proved inconsequential to émigré remittance-sending. Together, the results indicate that the assimilation paradigm by itself is insufficient to explain the variation in cross-border economic ties observed among different waves of first generation Cuban immigrants in Miami.

We also explored the explanatory power of two factors transnational analysts claim affect remittance-sending: household income and family-in-homeland. The presence of close family members in Cuba, but not income, was shown to be associated with higher odds of remittance-sending. While family-in-homeland was one of the strongest predictors of cross-border economic ties, inclusion of this variable in our models did not 
attenuate differences in remittance-sending between New Cubans and pre-1990s émigrés. This is because family-in-homeland is necessary, but not sufficient, to induce remittance-sending. Premigration historically-formed perspectives shape immigrants' proclivity to share earnings with family in their home country, independently of their income. The historical cohort thesis thereby builds on, but deepens, the understanding of dynamics the transnational paradigm addresses.

Our analysis, nonetheless, leaves a few issues unaddressed that, hopefully, future research will elucidate. For one, might historical cohort differences in remittancesending be institutionally explained by different transnational barriers in effect when immigrants uproot that shape remittance-sending habits in the long-run, even after barriers are lifted? Our research suggests, but does not prove, that historical cohort experiences influence cross-border economic ties even when institutional conditions become more conducive to cross-border income sharing. Two, validation of the historical cohort thesis ultimately rests on more detailed data that enables statistical separation of historical cohort and net duration effects. Hopefully, our analysis will inspire other studies, including of other immigrant groups. Evidence from studies of Dominican and Salvadoran immigrants do suggest that premigration experiences shape new country adaptation and transnational engagement. Only after experiencing homeland economic crises did a significant number of immigrants from these countries send remittances (Menjivar, 2000: 100; Landolt, Autler and Baires, 1999; Itzigsohn, Cabral, Medina and Vázquez, 1999). There also is evidence that diverse waves of immigrants from other countries experiencing social revolutions, namely Vietnam (Shelley, 2001), China (Kuhn, 2008; Pieke, Nyiri, Thuno and Ceccagno, 2004), and Poland (Erdmans 1998), relate differently to their homeland from their new land, with differences traceable to distinctive premigration experiences.

In sum, the differences among Cubans who uprooted at different times with different premigration experiences reveal that extant studies, which focus on contrasts between first and second generation immigrants, homogenize and ignore important differences in adaptation and transnational engagement among foreign-born. Our analysis calls for "new thinking," including for a new conceptual frame, to improve both our descriptive and theoretical understanding of immigrant experiences. It points to enduring crossborder influences of immigrants' pasts that both assimilation and transnational analyses, to date, have left undocumented and unexplained. The "new thinking" also calls for compilation of new data, in order to assess, better, how premigration experiences influence immigrant lives.

\section{Endnotes}

${ }^{1}$ For data on remittances to Latin America see Inter-American 2007, p. 7 and the World Bank (2015). See Eckstein 2009, pp. 178 and 179, and references therein, for a discussion of remittance estimates specifically for Cuba.

${ }^{2}$ This article is based on the situation that transpired before Raúl Castro announced in September 2010 that 500,000 Cubans would be released from their state sector jobs and permitted to pursue private employment, which might induce Cuban Americans to send more remittances and even invest in small Cuban family businesses (albeit in violation of the US embargo). 
${ }^{3}$ Portes, in collaboration with others (e.g., Portes and Zhou, 1993; Portes and Rumbaut, 1996) also addressed how the nature of assimilation varies with the groups with whom immigrants associate, connoted as "segmented assimilation."

${ }^{4}$ See Eckstein (2009), Chapter One for overview of Mannheim and Ryder theses.

${ }^{5}$ The kinds of immigration cohort analyses carried out by Borjas (1985), Myers and Lee (1996), Myers and Cranford (1998), as well as in this article, are distinct from studies of immigrant generations based on genealogical remove from the first in a family to emigrate. Generational cohort analyses based on genealogical remove are conceptually ahistoric.

${ }^{6}$ The 2000 but not 2007 poll included interviews with non-Cuban Americans in Miami-Dade County, as well as with Cuban Americans nationally. We focus exclusively on Cuban Americans in Miami-Dade, for which data are available for both years.

${ }^{7}$ The youngest birth cohort was dropped from the first observation period while the oldest birth cohort was dropped from the latest observation period (See Myers and Lee, 1998, p. 603 for further details on rationale behind sample selection for the double cohort design). We cut off the youngest age group at 30 because there were no Early Exiles younger than age 30 in the 2000 poll.

${ }^{8}$ A 2005 survey of first generation Cuban Americans age 18 and older in Florida by Bendixen and Associates found $39 \%$ to have sent remittances, whereas $31 \%$ of similarly aged émigrés in the FIU 2000 survey reported sending remittances. One might expect to see significantly higher proportions of remittance-senders in the FIU 2000 survey compared with the Bendixen and Associates survey if 'yes' responses to the FIU remittance question were being inflated by respondents reporting the remitting behavior of their relatives but not their own practices. The small difference in the proportion of remittance-senders in the two surveys suggests that variable misalignment is not a serious issue in our analysis.

${ }^{9}$ Citizenship is another indicator of acculturation. However, it is highly correlated with historical cohorts and therefore was not included as a covariate. Ninety-six per cent of Early Exiles and $91 \%$ of Late Exiles are US citizens. The proportions of naturalized citizens among Mariels and New Cubans are 65 and $33 \%$, respectively.

${ }^{10} \mathrm{We}$ exclude other characteristics cited in the literature as predictive of homeland engagement, namely motivation for emigration, frequency of homeland visits, and participation in ethnic organizations. The FIU survey did not query respondents about migration motivations. Respondents were asked about homeland visits, but because information on when visits took place was not queried we could not analyze transnational social engagement. Information about ethnic organization participation is not repeated in the two surveys.

${ }^{11}$ In preliminary analysis, we also explored the effects of education and political party affiliation on remittance-sending. However, because education was highly correlated with household income $(r=0.42)$, and not a statistically significant predictor of remittance-sending, we dropped it from the final analysis. Political party affiliation (Republican, Democrat, Independent) was also not a statistically significant predictor of remittance-sending because there is not enough variation in this variable. Most respondents, even among New Cubans, reported Republican as their party affiliation. 
${ }^{12}$ In additional exploratory analyses, we looked at the distribution of émigrés who reported still having close family in Cuba by age group for each historical cohort. We found that there were no statistically significant age-group differences in the proportion of émigrés who still had close family in Cuba among Early Exiles, $\left(\chi^{2}=1.1187\right.$, $p$-value $\left.=0.891\right)$, Late Exiles $\left(\chi^{2}=5.6054, \mathrm{p}\right.$-value $\left.=0.231\right)$, Mariels $\left(\chi^{2}=1.9209\right.$, $\mathrm{p}$-value $\left.=0.750\right)$, or $\mathrm{New}$ Cubans $\left(\chi^{2}=2.7923\right.$, $\mathrm{p}$-value $\left.=0.593\right)$. Thus, age differences in remittance-sending are not linked to to age-group variations in having close relatives in Cuba.

\section{Competing interests}

The authors declare that they have no competing interests.

\section{Authors' contributions}

ZV developed the analytical plan, carried out the statistical analysis, interpreted the results, and led the writing. SE developed the theoretical model from which the analysis is based. Both authors equally contributed to the final draft of the article. All authors read and approved the final manuscript.

\section{Acknowledgments}

We wish to thank Hugh Gladwin of Florida International University's Institute for Public Opinion Research for generously sharing data on which our analysis is based. We also wish to thank Manuel Orozco for kindly sharing additional data of his that enabled us to validate the remittance question in our analysis. Last but not least, we thank Christopher Winship, Peter DeWan, and Eran Shor for helpful comments on earlier drafts of this article.

\section{Author details}

'Department of Sociology, Centre on Population Dynamics, McGill University, 713 Leacock Building, 855 Sherbrooke Street, Montreal, QC H3A 2T7, Canada. ${ }^{2}$ Department of Sociology, Boston University, Boston, MA, USA.

Received: 12 May 2014 Accepted: 15 February 2015

Published online: 12 August 2015

\section{References}

Alba, RD, \& Nee, V. (2003). Remaking the American mainstream: assimilation and contemporary immigration. Cambridge, MA: Harvard University Press.

Bendixen, S. (2009). National Survey of Cuban Americans (p. 2009). Miami, FL: Bendixen and Associates.

Bendixen and Associates. (2005). Remittances to Cuba from the United States, May 25. http://bendixenandamandi.com/ wp-content/uploads/2010/08/IAD-Orozco-Cuban-Remittances-Presentation-2005.pdf.

Bilodeau, A. (2008). Immigrants' voice through protest politics in Canada and Australia: assessing the impact of pre-migration political repression. Journal of Ethnic and Migration Studies, 34(6), 975-1002.

Bloemraad, I. (2006). Becoming a citizen: incorporating immigrants and refugees in the united states and Canada. Berkeley: University of California Press.

Borjas, GJ. (1985). Assimilation, changes in cohort quality, and the earnings of immigrants. Journal of Labor Economics, 3(4), 463-489.

Chiswick, BR. (1978). The effects of Americanization on the earnings of foreign-born men. Journal of Political Economy, 86(5), 897-921.

Cuban Research Institute. (2015). FIU Cuba Poll. https://crifiu.edu/research/cuba-poll.

Del Toro, C. (2003). La Alta Burguesía Cubana 1920-1958. Havana: Editorial de Ciencias Sociales.

Diaz-Briquets, S, \& Perez-Lopez, J. (1997). Refugee remittances: conceptual issues and the Cuban and Nicaraguan experiences. International Migration Review, 31(2), 4111-4137.

Domínguez, MI. (2005). Cuban youth: aspirations, social perceptions, and identity. In JS Tulchin et al (Eds) with the collaboration of E. Bryan. Changes in Cuban Society since the Nineties (pp. 155-170). Washington, DC: Woodrow Wilson International Center for Scholars. Latin American Program.

Duany, J. (2011). Blurred borders: transnational migration between the Hispanic Caribbean and the United States. Chapel Hill, NC: University of North Carolina Press.

Eckstein, S. (2009). The immigrant divide: How Cuban Americans changed the US and their homeland. New York: Routledge.

Eckstein, S, \& Barberia, L. (2002). Grounding immigrant generations in history: Cuban Americans and their transnational ties. International Migration Review, 36(3), 799-837.

Eckstein, S, \& Krull, C. (2009). From building barriers to bridges: Cuban ties across the straits. Diplomacy and Statecraft, 20(2), 322-340.

Erdmans, MP. (1998). Opposite poles: immigrants and ethnics in polish Chicago, 1976-1990. University Park: Pennsylvania State University Press.

Glick-Schiller, N, Basch, L, \& Blanc-Szanton, C. (1992). Towards a transnational perspective on migration: race, class, ethnicity, and nationalism reconsidered. New York: New York Academy of Sciences.

Hernández, R. (2005). Mirror of Patience: Notes on Cuban Studies, Social Sciences, and Contemporary Thought. In JS Tulchin et al (Eds) with the collaboration of E. Bryan. Changes in Cuban Society since the Nineties (pp. 39-154). Washington DC: Woodrow Wilson International Center for Scholars. Latin American Program.

Hobcraft, J, Menken, J, \& Preston, S. (1982). Age, period, and cohort effects in demography: a review. Population Index, $48(1), 4-43$ 
Institute for Public Opinion Research/Florida International University (2004). FIU Cuba Poll, 2004. http://www2.fiu.edu/ ipor/cuba7/index.html.

Inter-American Dialogue (2007). Making the Most of Family Remittances. Washington, D.C.: Inter-American Dialogue, Task Force on Remittances.

Itzigsohn, J, Cabral, CD, Medina, EH, \& Vázquez, O. (1999). Mapping Dominican transnationalism: narrow and broad transnational practices. Ethnic and Racial Studies, 22(2), 316-339.

Itzigsohn, J, \& Saucedo, SG. (2002). Immigrant incorporation and sociocultural transnationalism. International Migration Review, 36(3), 766-798.

Kivisto, P. (2001). Theorizing transnational immigration: a critical review of current efforts. Ethnic and Racial Studies, 24(4), 549-578.

Kuhn, P. (2008). Chinese among others: emigration in modern times. Boulder, CO: Rowman and Littlefield.

Landolt, P, Autler, L, \& Baires, S. (1999). From Hermano Lejano to Hermano Mayor: the dialectics of Salvadoran transnationalism. Ethnic and Racial Studies, 22(2), 290-315.

Levitt, P. (2001). The transnational villagers. Berkeley: University of California Press.

Levitt, P, \& Glick-Schiller, N. (2004). Transnational perspectives on migration: conceptualizing simultaneity. International Migration Review, 38(145), 595-629.

Maldonado, R, \& Hayem, M. (2014). Remittances to Latin America and the Caribbean in 2013: Still Below Pre-Crisis Levels. Washington, D.C.: Multilateral Investment Fund, Inter-American Development Bank.

Mannheim, K. (1952). The problem of generations. In P Kecksckemeti (Ed.), Essays on the sociology of knowledge New York: Oxford University Press.

Massey, DS, Goldring, L, \& Durand, J. (1994). Continuities in transnational migration: an analysis of nineteen Mexican communities. American Journal of Sociology, 99(6), 1492-533.

Masud-Piloto, FR. (1995). From welcomed exiles to illegal immigrants: Cuban migration to the U.S., 1959-1995. Lanham, MD: Rowman \& Littlefield.

Menjivar, C. (2000). Fragmented ties: Salvadoran immigrant networks in America. Berkeley: University of California Press. Mesa-Lago, C. (2000). Market, socialist, and mixed economies. Baltimore: Johns Hopkins University Press.

Morales E. (2013). Cuba: $\$ 2.6$ billion in remittances in 2012. Havana Times June 11, 2013. http://www.havanatimes.org/?p=94444 Motel S., Patten E. (2012). The 10 largest Hispanic origin groups: Characteristics, rankings, top counties. Washington, DC: PEW. http:/www.pewhispanic.org/2012/06/27/the-10-largest-hispanic-origin-groups-characteristics-rankings-top-counties/

Myers, D, \& Cranford, CJ. (1998). Temporal differentiation in the occupational mobility of immigrant and native-born Latina workers. American Sociological Review, 63(1), 68-93.

Myers, D, \& Lee, SW. (1996). Immigration cohorts and residential overcrowding in Southern California. Demography, $33(1), 51-65$.

Myers, D, \& Lee, SW. (1998). Immigrant trajectories into homeownership: a temporal analysis of residential assimilation. International Migration Review, 32(3), 593-625.

Orozco, M. (2005). Remittance recipients in Cuba. Washington, D.C: Inter-American Dialogue.

Pieke, FN, Nyiri, P, Thuno, M, \& Ceccagno, A. (2004). Transnational Chinese: Fujianese migrants in Europe. Stanford, CA: Stanford University Press.

Portes, A, Guarnizo, LE, \& Landolt, P. (1999). The study of transnationalism: pitfalls and promise of an emergent research field. Ethnic and Racial Studies, 22(2), 217-237.

Portes, A, \& Rumbaut, RG. (1996). Immigrant America: a portrait. Berkeley, CA: University of California Press.

Portes, A, \& Stepick, A. (1993). City on the edge: the transformation of Miami. Berkeley: University of California Press.

Portes, A, \& Zhou, M. (1993). The new second generation: segmented assimilation and its variants. Annals of the American Political and Social Sciences, 530, 74-96.

Rumbaut, R. (2004). Ages, life stages, and generational cohorts: decomposing the immigrant first and second generations in the United States. International Migration Review, 38(3), 1160-1205.

Ryder, N. (1965). The cohort as a concept in the study of social change. American Sociological Review, 30(6), 843-861.

Schans, D. (2010). Transnational family ties of immigrants in the Netherlands. Ethnic and Racial Studies, 32(7), 1164-1182.

Shelley, NM. (2001). Building community from scratch: forces at work among urban Vietnamese refugees in Milwaukee. Sociological Inquiry, 71(4), 473-92.

Symmes, P. (2008). The boys from Dolores: Fidel Castro's schoolmates from revolution to exile. New York: Vintage Books.

Waldinger, R. (2008). Between 'here' and 'there': immigrant cross-border activities and loyalties. International Migration Review, 24(1), 3-29.

World Bank. (2015) Personal remittances, received (current US\$). http://data.worldbank.org/indicator/BX.TRF.PWKR.CD.DT.

\section{Submit your manuscript to a SpringerOpen ${ }^{\circ}$ journal and benefit from:}

- Convenient online submission

- Rigorous peer review

- Immediate publication on acceptance

- Open access: articles freely available online

- High visibility within the field

Retaining the copyright to your article

Submit your next manuscript at $\boldsymbol{\wedge}$ springeropen.com 